\title{
The future of lab animal facilities in Brazil
}

\author{
Alexandre Viecili \\ From 5th Congress of the Brazilian Biotechnology Society (SBBIOTEC) \\ Florianópolis, Brazil. 10-14 November 2013
}

The evolution of rodents cages marked major improvements of animal and staff protection. Aspects pertaining to animal welfare and the need for higher flexibility in space used led to the development and success of Individually Ventilated Cages (IVCs), extensively used in modern animal facilities. The concept of "room at cage level" along with the latest innovations in IVCs will be reviewed.

The presentation will highlight how specific abilities to provide native integration among IVCs, laminar flow equipment, washing and decontamination equipment and potentially automation can lead to more efficient planning and later effective exploitation of Lab Animal facilities, as well as to significant bottom.

Published: 1 October 2014

doi:10.1186/1753-6561-8-S4-028

Cite this article as: Viecili: The future of lab animal facilities in Brazil.

BMC Proceedings 2014 8(Suppl 4):O28.

Instrulab, Porto Alegre, Rio Grande do Sul, Brazil

Submit your next manuscript to BioMed Central and take full advantage of:

- Convenient online submission

- Thorough peer review

- No space constraints or color figure charges

- Immediate publication on acceptance

- Inclusion in PubMed, CAS, Scopus and Google Scholar

- Research which is freely available for redistribution

Submit your manuscript at www.biomedcentral.com/submit
( Biomed Central 